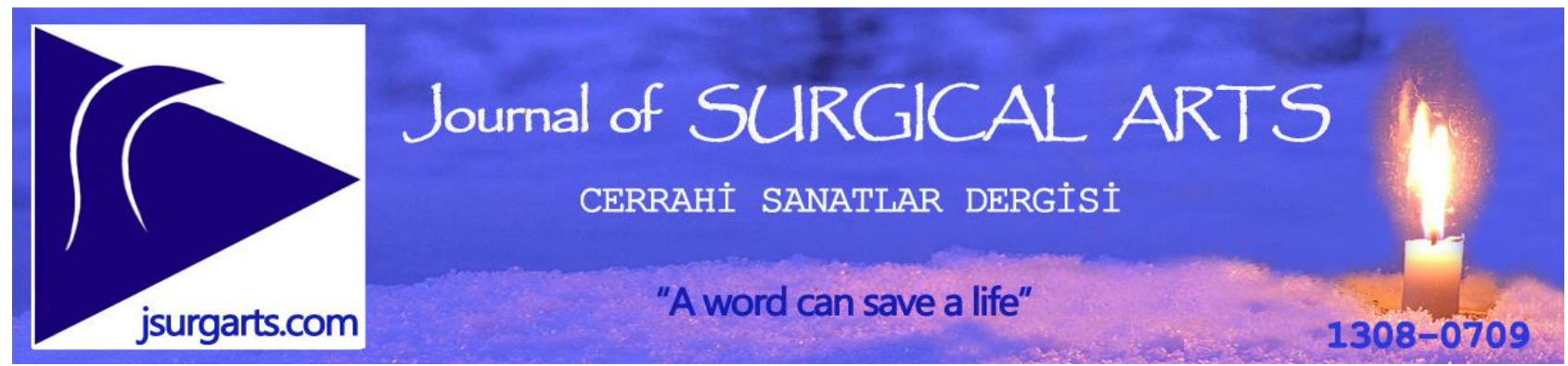

Original study

\title{
A clinical study of varicose veins and their management in patients attending the surgical department of a tertiary hospital
}

\section{Üçüncü basamak bir hastanenin cerrahi bölümüne başvuran hastalarda varisli damarlar ve yönetimi üzerine klinik bir çalışma}

\author{
Vikram Yogish iD, Sugandh Arockiyasekar iD, Akhil Avirneni iD \\ Department of General Surgery, SRM Medical College Hospital and Research Centre, SRM Institute of Science \\ and Technology, Kattankulathur, Tamil Nadu, India.
}

Address: Dr.VikramYogish, vikaramy@srmist.edu.in

How to cite: Yogish V, Arockiyasekar S, Avirmeni A. A clinical study of varicose veins and their management in patients attending the surgical department of a tertiary hospital. J Surg Arts 2021;14(2):65-68.

DOI: http://dx.doi.org/10.14717/jsurgarts-210203

Received: 28.04.2021 Accepted: 05.07.2021

\section{ABSTRACT}

Varicose veins are abnormally dilated, tortuous and elongated veins that occur in the lower limbs. The patients usually present to the surgical outpatient department with various clinical presentations such as, dilated veins, venous ulcers over the legs, pigmentation of the skin and lipodermatosclerosis to name a few. Venous doppler is a very important investigation that must be done in a cases of varicose veins. The surgical treatment involves sapheno-femoral junction flush ligation with stripping of the varicose vein. Several other modalities are also available today such as, sclerotherapy and endovascular laser ablation (EVLA).

The objective of this study was to determine the clinical profile of the patients who presented with varicose veins and to determine the treatment that was offered to them to treat the varicose veins. This study was carried out from September 2015 to August 2018. A total of 62 patients were studied. The statistics were analysed using SPSS package 20.0. Ethical clearance was obtained from the institutional ethics committee.

The presence of dilated veins was the most common complaint with which patients presented to the surgical outpatient department. The most common surgical procedure that was performed was the sapheno-femoral junction flush ligation with stripping of the varicose vein. This study shows the importance of diagnosing a case of varicose veins and to determine as early as possible the treatment modality that should be offered to the patient.

Keywords: Varicose veins, venous doppler, dilated veins, venous ulcers.

\section{ÖZET}

Varisli damarlar, alt ekstremitelerde meydana gelen anormal şekilde genişlemiş, kıvrımlı ve uzamış damarlardır. Hastalar genellikle genişlemiş damarlar, bacaklarda venöz ülserler, deride pigmentasyon ve lipodermatoskleroz gibi çeşitli klinik tablolarla cerrahi polikliniğine başvururlar. Venöz doppler, varisli damarlarda mutlaka yapılması gereken çok önemli bir tetkiktir. Cerrahi tedavi variköz venin soyulması ile safeno-femoral bileşke ligasyonunu içerir. Günümüzde skleroterapi ve endovasküler lazer ablasyon (EVLA) gibi başka yöntemler de mevcuttur.

Bu çalışmanın amacı varis ile başvuran hastaların klinik profilini belirlemek ve varis tedavisi için kendilerine sunulan tedaviyi belirlemekti. Toplam 62 hasta incelendi. İstatistikler SPSS paketi 20.0 kullanılarak analiz edildi. Kurumsal etik kuruldan etik izin alındı. 
Genişlemiş damar varlığı hastaların cerrahi polikliniğine en sık başvurduğu şikayetti. Uygulanan en yaygın cerrahi prosedür, varisli damarın soyulması ile safeno-femoral bileşke yıkama ligasyonu idi. Bu çalışma, bir varis olgusunun teşhis edilmesinin ve hastaya sunulması gereken tedavi yönteminin mümkün olduğunca erken belirlenmesinin önemini göstermektedir.

Anahtar kelimeler: Variköz ven, venös doppler, dilate ven, venöz ülser.

\section{INTRODUCTION}

Varicose veins are abnormally dilated, tortuous and elongated veins that occur in the lower limbs. This is usually found due standing for a prolonged duration of time and hence, also depends on the occupation of the patient. The patients usually present to the surgical outpatient department with various clinical presentations such as, dilated veins, venous ulcers over the legs, pigmentation of the skin and lipodermatosclerosis to name a few. Along with investigations such as complete blood count (CBC) and other routine blood investigations, venous doppler of the lower limbs must be done and is a very important investigation in cases of varicose veins. Ultrasound of the abdomen may also have to be done especially in cases where the patient presents with varicose veins in both the lower limbs. A detailed history must be collected and a thorough clinical examination must be done. The surgical treatment involves sapheno-femoral junction flush ligation with stripping of the varicose vein. Several other modalities are also available today such as, sclerotherapy and endovascular laser ablation (EVLA).

The objective of this study was to determine the clinical profile of the patients who presented with varicose veins and to determine the treatment that was offered to them to treat the varicose veins.

\section{MATERIAL and METHOD}

This study was carried out from September 2015 to August 2018 for a period of three years. The study was carried out at SRM Medical College Hospital and Research Centre, Kattankulathur, Tamil $\mathrm{Nadu}$, India. Investigations such as complete blood count (CBC), venous doppler of the lower limbs and ultrasound of the abdomen were done. A detailed history was collected and a thorough clinical examination was done. A total of 62 patients were studied.The statistics were analysed using SPSS package 20.0. Ethical clearance was obtained from the institutional ethics committee.

\section{RESULTS}

From the below tables, it is seen that in our study, the most common age group of that was affected with varicose veins was between 41-50 years and, men were more affected than women. In our study, the right leg was found to be more commonly affected with varicose veins. The patients most commonly presented with the complaint of dilated veins over the lower limbs. The most common surgical procedure that was done in our study was the sapheno-femoral junction flush ligation with stripping of the varicose vein.

\begin{tabular}{|c|c|c|}
\hline \multicolumn{3}{|c|}{ Table 1: Age group of the patients. } \\
\hline Age (Yrs) & Patients (n) & $\%$ \\
\hline $20-30$ & 2 & 3.22 \\
\hline $31-40$ & 12 & 19.35 \\
\hline $41-50$ & 20 & 32.25 \\
\hline $51-60$ & 17 & 27.41 \\
\hline $61-70$ & 11 & 17.74 \\
\hline
\end{tabular}

\begin{tabular}{|l|c|c|}
\hline \multicolumn{3}{|c|}{ Table 2: Gender of the patients. } \\
\hline \multicolumn{1}{|c|}{ Gender } & Patients (n) & \% \\
\hline Male & 45 & 72.58 \\
\hline Female & 17 & 27.41 \\
\hline
\end{tabular}

Table 3: Side of the lower extremity affected.

\begin{tabular}{|l|c|c|}
\hline \multicolumn{1}{|c|}{ Side } & Patients (n) & \% \\
\hline Right leg & 37 & 59.67 \\
\hline Left leg & 25 & 40.32 \\
\hline
\end{tabular}

Table 4: Clinical presentation modes of the patients.

\begin{tabular}{|l|c|c|}
\hline \multicolumn{1}{|c|}{ Modes } & Patients (n) & \% \\
\hline Dilated veins only & 45 & 72.58 \\
\hline $\begin{array}{l}\text { Dilated veins with } \\
\text { venous ulcers }\end{array}$ & 10 & 16.12 \\
\hline $\begin{array}{l}\text { Dilated veins with } \\
\text { pigmentation of the } \\
\text { skin }\end{array}$ & 7 & 11.29 \\
\hline
\end{tabular}

Table 5: Treatment given to patients.

\begin{tabular}{|l|c|c|}
\hline \multicolumn{1}{|c|}{ Treatment } & $\begin{array}{c}\text { Patients } \\
\text { (n) }\end{array}$ & $\%$ \\
\hline $\begin{array}{l}\text { Sapheno-femoral junction } \\
\text { flush ligation with stripping } \\
\text { of the varicose vein }\end{array}$ & 40 & 64.51 \\
\hline Sclerotherapy & 12 & 19.35 \\
\hline Conservative & 10 & 16.12 \\
\hline
\end{tabular}

\section{DISCUSSION}

The occupation of the patient plays a very important role in the development of varicose veins. People who have to stand for a prolonged duration of time are more likely to be affected with varicose veins 
than others. Patients who present to the surgical outpatient department must be carefully examine $\mathrm{d}$ and a detailed history must also be collected. A very important investigation to be done for varicose veins is the venous Doppler of the lower limbs. Wills et al showed in his study the use of the venous doppler in determining sapheno-femoral incompetence, sapheno-popliteal incompetence and perforator incompetence.Kim et al also showed in their study, the high sensitivity and specificity of the handheld Doppler in cases of varicose veins (1). Irodi A et al showed in their study that, even when the perforators alone are found to be incompetent, the doppler is the ideal investigation to detect the number and the distribution of the incompetent perforators (2). Vashist et al have also shown in their study that the venous doppler is a very important investigation that should be done in cases of varicose veins (3).

The long saphenous vein and the short saphenous vein must be examined individually as the problem can be present in either one. In the study done by Delbe and Mocquet, the varicosities were found in the long saphenous vein in $98 \%$ of patients and in the short saphenous vein in $2 \%$ of the patients (4). Sometimes, the perforators alone may be incompetent and so a detailed clinical examination is also very important. Labropoulos et al, in their study showed that the perforators were incompetent in $68 \%$ of the patients (5). There are several modalities of treatment available today for varicose veins (6). These may range from, conservative management to surgery. The surgical treatment involves sapheno-femoral junction flush ligation with stripping of the varicose vein segments. Some of the other methods of treatment that can be offered to the patient include, radiofrquencey ablation, ultrasound guided foam sclerotherapy and endovascular laser ablation (EVLA). In our study, $64.51 \%$ underwent sapheno-femoral junction flush ligation with stripping of the varicose vein and $19.35 \%$ underwent sclerotherapy. Subbarao et al performed a study for the treatment of varicose veins using sclerosant and they showed that patients had significant improvement symptomatically (7). See the tables 6-10 for detailed information) (7-19).

Table 6: Comparison of average age of occurrence of varicose veins between our study and another study.

\begin{tabular}{|c|c|c|}
\hline Average & ${\text { Vaidyanathan et } \mathbf{a l}^{\mathbf{8}}}^{\mathbf{8}}$ & Our study \\
\hline Age (Years) & 39 years & 48.32 years \\
\hline
\end{tabular}

Table 7: Sexwise comparison of occurrence of varicose veins between our study and other studies.

\begin{tabular}{|l|c|c|c|}
\hline Gender & Mirji et al ${ }^{\mathbf{9}}$ & Pavan et al $^{\mathbf{1 0}}$ & Our study $^{\mathbf{2}}$ \\
\hline Male & $75 \%$ & $25 \%$ & $72.58 \%$ \\
\hline Female & $78 \%$ & $22 \%$ & $27.41 \%$ \\
\hline
\end{tabular}

Table 8: Comparison of the side of the affected limb between our study and other studies.

\begin{tabular}{|c|c|c|c|c|}
\hline Side & Barros et al $^{\mathbf{1 1}}$ & Hoare et al $^{\mathbf{1 2}}$ & Dur et al $^{\mathbf{1 3}}$ & Our study $^{\text {Right leg }}$ \\
\hline Left leg & $37.8 \%$ & $47.8 \%$ & $48.55 \%$ & $59.67 \%$ \\
\hline $41.7 \%$ & $52.2 \%$ & $51.45 \%$ & $40.32 \%$ \\
\hline
\end{tabular}

Table 9: Comparison of presence of dilated veins between our study and other studies.

\begin{tabular}{|c|c|c|c|c|}
\hline Clinical presentation & Shankar et al ${ }^{14}$ & Rudofsky et al ${ }^{15}$ & $\mathrm{O}^{6}$ Shaughnessy et al ${ }^{16}$ & Our study \\
\hline Dilated veins & $90 \%$ & $92 \%$ & $84 \%$ & $72.58 \%$ \\
\hline
\end{tabular}

\begin{tabular}{|c|c|c|c|c|c|}
\hline \multicolumn{6}{|c|}{ Table 10: Comparison of presence of venous ulcers between our study and other studies. } \\
\hline Clinical presentation & $\begin{array}{c}\text { Vaidyanathan } \\
\text { et al }^{\mathbf{8}}\end{array}$ & Bashir et al ${ }^{\mathbf{1 7}}$ & $\begin{array}{c}\text { Sharma et } \\
\mathbf{a l}^{\mathbf{1 8}}\end{array}$ & Jami et al 19 & Our study \\
\hline $\begin{array}{c}\text { Dilated veins with } \\
\text { venous ulcers }\end{array}$ & $46.67 \%$ & $8 \%$ & $42 \%$ & $21.81 \%$ & $16.12 \%$ \\
\hline
\end{tabular}




\section{Conclusion}

From our study, it is seen that the most common occurrence of varicose veins is between the age group of 41-50 years and men were more affected with varicose veins than women. The presence of dilated veins was the most common complaint with which patients presented to the surgical outpatient department. The most common surgical procedure that was performed was the sapheno-femoral junction flush ligation with stripping of the varicose vein. This study shows the importance of diagnosing a case of varicose veins and to determine as early as possible the treatment modality that should be offered to the patient.

\section{REFERENCES}

1. Wills V, Moylan D, Chambers J. The use of routine duplex scanning in the assessment of varicose veins. Australian and New Zealand J Surg. 1998;68(1):41-44.

2. Kim J, Richards S, Kent PJ. Clinical examination of varicose veins- A validation study. Ann R Coll Surg Engl. 2000;82:171-175.

3. Irodi A, Keshava SN, Agarwal S, Sadhu D. Standardisation of preoperative marking of incompetent perforators and saphenopopliteal junction on Doppler with evaluation of " $t$ " technique. Indian J Surg 2011;73:37-39.

4. Vashist M, Godara G, Rajesh R, Sen J, Panwar $S$. Management of varicose veins: Status of clinical examination and colour Doppler in the present Indian scenario. Internet $\mathbf{J}$ Surg. 2013;20:7613.

5. Delbe and Mocquet. Varicose veins and deep vein thrombosis: epidemiology and suggested aetiology. Br Med J. 2005;2:556.

6. Labropoulos N, Giannoukas AD, Delis K, Mansour MA, Kang SS, Nicolaides AN, et al. Where does venous reflux start?. J Vascular Surg. 1997;26(5):736-742.

7. Subbarao NT, Aradhya SS, Veerabhadrappa NH. Sclerotherapy in the management of varicose veins and its dermatological complications. Indian J Dermatol Venereol Leprol. 2013;79(3):383-388.

8. Vaidyanathan S. Deep vein obstruction: management strategies. In: Chronic venous disorders of the lower limbs. Springer; 2015, p:195203.

9. Mirji P, Emmi S, Joshi C. Study of clinical features and management of varicose veins of lower limb. J Clin Diagn Res. 2011;5(7):14161420.

10. Pavan Prasad BK, Prem Kumar A. Clinical study of varicose veins and their management. Int J Biomed Advance Res. 2015;6(08):564568.

11. Barros FS, Perez JM, Zandonade E, SallesCunha SX, Monedero JL, Hilel AB, et al. Evaluation of pelvic varicose veins using color
Doppler ultrasound: comparison of results obtained with ultrasound of the lower limbs, transvaginal ultrasound, and phlebography. J Vascular Brasileiro. 2010;9(2):15-23.

12. Hoare MC. The role of primary varicose veins in venous ulceration. Comprehensive Vascular and Endovascular Surgery: Expert Consult. 1982;92:450-453.

13. Dur AHM, Mackaay AJC. Duplex assessment of clinically diagnosed venous insufficiency. Br J Surg. 1992;79:155-161.

14. Shankar KH. Clinical study of varicose veins of lower limbs. Internat Surg J. 2017;4(2):633636.

15. Rudofsky G. Epidemiology and pathophysiology of primary varicose veins. Langenbecks Arc Chir. 1988;2:139-144.

16. O‘ Shaughnessy M, Rahall E, Walsh TN, Given HF. Surgery in the treatment of varicose veins. Ir Med J. 1989;82(2):54-55.

17. Bashir J, Das K, Ahuja P, Arain MS. Clinical features and risk factors of varicose veins at $\mathrm{Li}$ aquat University Hospital Hyderabad. Pak J Surg. 2013;29(2):127-130.

18. Sharma S, Pandey S, Bhatnagar A. Clinical study of 50 patients of varicose veins in NSCB Subharti Hospital, Meerut,(UP) with special reference to Clinical examination vs Color Doppler for evaluation and diagnosis of varicose veins. Inter J Scient Res. 2018;20;6(4).

19. Jami V, Kumar TP. A clinical study on varicose veins of lower limbs. Global J Res Analysis. 2018;7(6):75-77. 